\title{
Fenneropenaeus indicus is protected from white spot disease by oral administration of inactivated white spot syndrome virus
}

\author{
I. S. Bright Singh ${ }^{1, *}$, M. Manjusha ${ }^{1}$, S. Somnath Pai ${ }^{1}$, Rosamma Philip ${ }^{2}$ \\ ${ }^{1}$ Centre for Fish Disease Diagnosis and Management, and ${ }^{2}$ Department of Marine Biology, Microbiology and Biochemistry, \\ Cochin University of Science and Technology, Lakeside Campus, Fine Arts Avenue, Kochi - 682 016, Kerala, India
}

\begin{abstract}
Fenneropenaeus indicus could be protected from white spot disease (WSD) caused by white spot syndrome virus (WSSV) using a formalin-inactivated viral preparation (IVP) derived from WSSV-infected shrimp tissue. The lowest test quantity of lyophilized IVP coated onto feed at $0.025 \mathrm{~g}^{-1}$ (dry weight) and administered at a rate of $0.035 \mathrm{~g}_{\text {feed }} \mathrm{g}^{-1}$ body weight $\mathrm{d}^{-1}$ for 7 consecutive days was sufficient to provide protection from WSD for a short period (10 d after cessation of IVP administration). Shrimp that survived challenges on the 5th and 10th days after cessation of IVP administration survived repeated challenges although they were sometimes positive for the presence of WSSV by a polymerase chain reaction (PCR) assay specific for WSSV. These results suggest that F. indicus can be protected from WSD by simple oral administration of IVP.
\end{abstract}

KEY WORDS: Penaeus indicus $\cdot$ Penaeid shrimp $\cdot$ White spot syndrome virus $\cdot$ Vaccination

\section{INTRODUCTION}

Appropriate measures to manage white spot syndrome virus (WSSV) have been of great interest ever since its emergence as the single most important pathogen of cultivated shrimp. Despite the implementation of several management practices such as avoidance, optimization of culture conditions and application of immunostimulants, probiotics or vitamins, the disease continues to cause severe losses. The belief that invertebrates lack specific immunoglobulins has hindered deliberate attempts to vaccinate shrimp against WSSV (Faye 1990). Although no antibodies have been detected in invertebrates, several molecules belonging to the immunoglobulin superfamily (IgSF) and involved in the immune response have been documented (Mendoza \& Faye 1996). These include adhesion molecules (Mendoza \& Faye 1996) such as catherins, Ig-like proteins, extracellular matrix proteins, tiggrin (Johansson 1999), peroxinectin (Johansson \& Soderhall 1988, 1989, Johansson et al. 1995), haemolin (Sun et al. 1990, Ladenhorff \& Kanost 1991, Bettencourt et al. 1997), limulus agglutination-aggregation factor (LAF), hemocytin, A74 protein, croquemort, plasmocyte spreading peptide (PSPI) and Drosophila Toll/Cactus/Dorsal proteins (TCD) (AralaChaves \& Sequeira 2000). However, it is believed that shrimp and other crustaceans do not possess adaptive immunity but, rather, that they possess only an innate immunity that includes a diverse array of humoral and cellular factors. These include phagocytosis and melanization by activation of the prophenol oxidase activating system, clotting processes, encapsulation of foreign material, antimicrobial peptides, cytotoxic 
reactive oxygen intermediates (ROI) and agglutination. Non-self recognition factors include lectins, lipoproteins and cell to cell communication molecules (Soderhall \& Cerenius 1992).

Past research has focused primarily on understanding these non-specific crustacean defense mechanisms, and work on vaccines against specific pathogens such as WSSV has not been pursued seriously. Nevertheless, effective protection of Penaeus monodon and Marsupenaeus japonicus against vibriosis with formalin-killed Vibrio sp. has been reported (Itami et al. 1989, 1992, Teunissen et al. 1998). The mechanism of protection remains unexplained and may be an adaptive secondary immune response, homologous to that observed in vertebrates, or a distinct crustacean type of immunoprotective pathway (Arala-Chaves \& Sequeira 2000). The presence of bactericidins in $P$. monodon hemolymph after exposure to heat-killed $V$. alginolyticus has been reported (Adams 1991) and would seem to demonstrate some type of immune memory (Teunissen et al. 1998). For viral pathogens, a process of specific and active viral accommodation has been postulated (Flegel \& Pasharawipas 1998). A requirement for the viral accommodation hypothesis was the existence of specific memory that could prevent viral triggered apoptosis but could not prevent viral infection. The hypothesis proposed that exposure of young larval stages to inactivated viral particles or sub-unit viral proteins ('tolerines' as opposed to vaccines) would result in innocuous, persistent viral infections rather than mortality upon subsequent viral challenge (Flegel \& Pasharawipas 1998).

A quasi-immune response to WSSV (known as penaeid rod-shaped DNA virus or PRDV in Japan) was reported for Marsupenaeus japonicus survivors from a farm outbreak of WSD that were able to survive a subsequent experimental super-challenge (Venegas et al. 2000). Similar incidents have occurred on shrimp farms at Kerala, India, where successful harvests resulted after an earlier viral outbreak. These previous reports and our observations prompted us to examine the possibility of protecting shrimp against WSSV using a formalin-inactivated viral preparation (IVP). This work was originally submitted for publication in May 2003 but suffered publication delays. In the meantime, Namikoshi et al. (2004) claimed the first successful 'vaccination' in shrimp against WSSV by demonstrating protection of $M$. japonicus from WSSV by intramuscular injection of formalin-inactivated WSSV or recombinant viral protein rVP28. Later, Witteveldt et al. $(2004 a, b)$ reported similar results using 2 WSSV envelope proteins, VP19 and VP28. Our work is discussed in this context and its practical utility is examined.

\section{MATERIALS AND METHODS}

Virus strain. A strain of WSSV (MCCV101) from the microbial culture collection of the Centre for Fish Disease Diagnosis and Management, Cochin University of Science and Technology, India, was used for the experiment. This virus was originally isolated in 1995 from a Penaeus monodon spawner and was continuously passed through several batches of quarantined WSSV-free Fenneropenaeus indicus. It was stocked at $-35^{\circ} \mathrm{C}$ in shrimp tissue. The virus was confirmed as WSSV by histopathology, electron microscopy and diagnostic nested PCR (Fig. 1).

To generate a sufficient quantity of virus for experiments, frozen stock tissue was thawed and fed to quarantined Fenneropenaeus indicus maintained in rearing tanks as described below. Moribund shrimp were examined for characteristic white spots within the cuticle and then stored at $-35^{\circ} \mathrm{C}$ until required for inactivated viral preparation (IVP).

Maintenance of experimental animals. Juvenile Fenneropenaeus indicus (average body weight of 3 to $4 \mathrm{~g}$ ) were brought to the laboratory and quarantined for $48 \mathrm{~h}$. Those that started eating pelleted diet were transferred to rearing tanks where salinity was gradually adjusted to 20 parts per thousand (ppt). They were subjected to stress testing by exposure to $100 \mathrm{ppm}$ for-

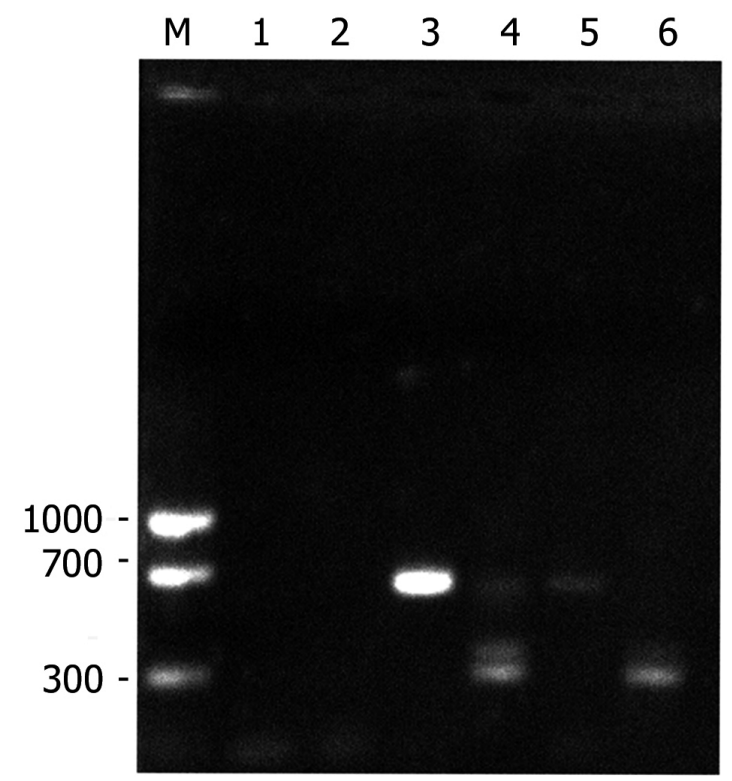

Fig. 1. Agarose gel showing 2-step PCR amplification of 650 and $300 \mathrm{bp}$ fragments of WSSV MCCV101 in the gill tissue of infected Fenneropenaeus indicus. Lane M: marker (1000, 700, and $300 \mathrm{bp})$; Lane 1: 1-step PCR negative control; Lane 2: 2-step PCR negative control; Lane 3: 1-step PCR positive control; Lane 4: 2-step PCR positive control; Lane 5: 1-step PCR amplification product from $F$. indicus infected with WSSV MCCV101; Lane 6: 2-step PCR amplification product from $F$. indicus infected with WSSV MCCV101 
malin for $1 \mathrm{~h}$ before survivors only were returned to fiber reinforced plastic (FRP) rectangular tanks (30 l) for experiments. Water quality was monitored daily to maintain $\mathrm{pH}$ at 7.5 to 8.5 , salinity at 20 to $22 \mathrm{ppt}, \mathrm{NH}_{3}$ at 0.01 to $0.02 \mathrm{ppm}, \mathrm{NO}_{2}$ at 0.1 to $0.2 \mathrm{ppm}$ and dissolved oxygen at 6 to $7 \mathrm{mg}$ oxygen $\mathrm{l}^{-1}$. Water was partially exchanged whenever the values deviated. Aeration was provided through air spargers from a $746 \mathrm{~W}$ compressor. The shrimp were fed ad libitum twice daily with commercial pelleted feed (Grower).

Virus titre. Viral infectivity titre for Fenneropenaeus indicus was estimated as extractable virus $\mathrm{g}^{-1}$ of infected stock tissue and expressed as lethal dose $\left(\mathrm{LD}_{50}\right)$ following Reed \& Muench (1938). Briefly, $1 \mathrm{~g}$ WSSV MCCV101 infected stock tissue was thoroughly macerated in a minimum quantity of phosphate buffered saline (PBS) $(8 \mathrm{~g} \mathrm{NaCl}, 0.2 \mathrm{~g} \mathrm{KCl}, 1.15 \mathrm{~g}$ $\mathrm{Na}_{2} \mathrm{HPO}_{4}, 0.2 \mathrm{~g} \mathrm{KH} \mathrm{PO}_{4}, 1000 \mathrm{ml} \mathrm{ddH}_{2} \mathrm{O}$ ) with an equal quantity of glass fibre wool and made into a slurry that was centrifuged at $8200 \times g$ for $20 \mathrm{~min}$ at $4^{\circ} \mathrm{C}$. The supernatant was removed, made up to $7 \mathrm{ml}$ using PBS and filtered through a $0.22 \mu \mathrm{m}$ polyvinylidene fluoride (PVDF) membrane (Millipore). From this filtered viral extract, serial dilutions were prepared up to $10^{-20.85}$ using PBS. Dilutions $\left(10^{-1.85}\right.$ to $\left.10^{-20.85}\right)$ were injected into batches of 6 shrimp (10 $\mu$ l each) and the $\mathrm{LD}_{50} \mathrm{~g}^{-1}$ of the infected tissue was calculated from the reciprocal of the dilution that caused $50 \%$ mortality.

Inactivated virus preparation. Infected stock tissue was homogenized in sterile seawater ( $2 \%$ salinity) at a ratio of $15 \mathrm{~g}$ to $100 \mathrm{ml}$ in a tissue homogenizer and passed through a $100 \mu \mathrm{m}$ mesh sieve to ensure uniformity. It was then subjected to 2 successive cycles of freezing and thawing to release virus from the tissue particles. To ensure that the suspension contained WSSV, $0.01 \mathrm{ml}$ was injected into each of two $10 \mathrm{~g}$ healthy Fenneropenaeus indicus immediately after preparation. These were then observed for clinical signs of WSD and mortality for $10 \mathrm{~d}$. The preparation was inactivated by addition of formalin (Qualigens) to a final concentration of $0.2 \%(\mathrm{v} / \mathrm{v})$ and incubation at room temperature $\left(28 \pm 1^{\circ} \mathrm{C}\right)$ for $48 \mathrm{~h}$. The IVP was then stored at $4^{\circ} \mathrm{C}$ until used. To examine for sterility, a loop-full of the IVP suspension was streaked onto ZoBell's and Sabouraud dextrose agar plates (prepared using 20 ppt seawater) that were incubated for $7 \mathrm{~d}$. As a control (placebo), head soft tissue of apparently healthy animals (tested negative by diagnostic PCR) was treated as above and maintained at $4^{\circ} \mathrm{C}$ until used. Aliquots of $10 \mathrm{ml}$ preparations (both test and placebo) were absorbed onto $5 \mathrm{~g}$ of pelleted feed (Grower), air dried briefly and continuously fed to batches of 8 juveniles in triplicate for $9 \mathrm{~d}$ at intervals of $24 \mathrm{~h}$. All animals were observed to ensure lack of clinical signs of WSD and lack of mortality for $7 \mathrm{~d}$.
Efficacy of IVP in preventing WSD. IVP and the placebo were lyophilized (FTS Systems) to yield $35.6 \mathrm{~g}$ dry mass from $500 \mathrm{ml}$ of tissue suspension prepared from $75 \mathrm{~g}$ of infected tissue. The lyophilized material was coated onto pelleted feed (Grower) at a ratio of 1:10 (w/w) using a commercial binder ('Bindex', Matrix Vet Pharma) at a ratio of $0.1: 10 \mathrm{v} / \mathrm{w}$ and dried in vacuum desiccator for $2 \mathrm{~d}$. After drying, the preparation was maintained in airtight containers at $4^{\circ} \mathrm{C}$.

Twelve FRP tanks (25 l) were set up with 4 shrimp in each. Four tanks received IVP coated feed, 4 placebo, and 4 normal feed. Feeding was ad libitum but was later determined to be $0.035 \mathrm{~g}$ feed $\mathrm{g}^{-1}$ body weight $\mathrm{d}^{-1}$. Feeding was continued for $7 \mathrm{~d}$ before all tanks were switched to normal feed. There was no cannibalism. The shrimp were challenged ( 1 tank at a time for each group) on the 1st, 5th, 10th and 15th day after the completion of the initial $7 \mathrm{~d}$ administration schedule. Thawed WSSV MCCV101-infected shrimp meat maintained at $-35^{\circ} \mathrm{C}$ was used for the challenge at a rate of approximately $1 \mathrm{~g}$ infected tissue for 4 animals. This was given after all uneaten feed and fecal matter had been removed and after partial water exchange. On all other days, the shrimp were maintained on a normal diet. After challenge, the shrimp were observed for clinical signs of the disease and mortality for $10 \mathrm{~d}$. The experiment was repeated 6 times. Shrimp that survived the 5th and 10th day challenges were subjected to repeated WSSV MCCV101 prawn meat challenges at intervals of $15 \mathrm{~d}$ for 4 consecutive times.

Quantity of IVP required. Initial tests used IVP incorporated into the feed at 1:10 (w/w) and the feed was consumed at a rate of $35 \mathrm{~g} \mathrm{~kg}^{-1}$ shrimp body weight $\mathrm{d}^{-1}$. Further tests were carried out to determine the minimum quantity of IVP required for WSD protection. Accordingly, tests were repeated in batches of 12 as described above but using experimental diet coated with $0.25,0.5,0.75$ and $1.0 \mathrm{~g}$ of lyophilized IVP per $10 \mathrm{~g}$ feed. Corresponding control sets of animals were maintained on a normal diet. The overall duration of IVP administration was $7 \mathrm{~d}$ and the shrimp were challenged in 2 consecutive steps, half on the 5th day after completion of IVP administration and half on the 10th day. The experiment was repeated 3 times.

PCR testing for WSSV. Gill samples from shrimp that survived viral challenges were pooled and tested for the presence of WSSV employing a WSSV 2-step nested PCR detection kit (Bangalore Genei) that yields 650 and $300 \mathrm{bp}$ WSSV-specific amplicons. The PCR products were then analyzed on $2 \% \mathrm{w} / \mathrm{v}$ agarose gels using TAE (1X) as the running buffer (Tris-HCl 0.04 M, EDTA $0.0001 \mathrm{M}$, glacial acetic acid $5.71 \%$ ), staining by ethidium bromide and visualization on a UV transilluminator (Hoefer, Macro Vue UV-20). Following the kit instructions, the expected amplicons were obtained 
using an MJ Research, PTC-150 thermocycler with stored WSSV MCCV101 samples.

\section{RESULTS}

The viral titre for $\mathrm{LD}_{50}$ of the WSSV MCCV101 viral extract solution was $1 \times 10^{13.69} \mathrm{ml}^{-1}$ of inoculum. This value could be used to calculate that the WSSV titre of the WSSV MCCV101 tissue used was $7 \times 10^{13.69} \mathrm{~g}^{-1}$ (wet weight). Accordingly the titre of the lyophilized IVP was calculated to be $14.75 \times 10^{13.69} \mathrm{~g}^{-1}$ (dry weight).

The IVP was shown to contain no viable WSSV after treatment with formalin $(0.2 \% \mathrm{v} / \mathrm{v})$ for $48 \mathrm{~h}$ at room temperature since there was $100 \%$ survival during a period of $7 \mathrm{~d}$ for the shrimp (batches of 8 in triplicate) fed with the preparation. No bacterial or fungal growth was observed in any of the inactivated virus suspensions streaked onto standard media plates.

Shrimp challenged with WSSV on the 5th and 10th day after cessation of feeding with IVP showed 100\% survival, while those challenged on the 1st and 15th day after cessation suffered mortality, with clinical manifestations of WSD (Table 1). Likewise, all WSSVchallenged shrimp in normal feed control and placebo control suffered total mortality and exhibited clinical signs of WSD within $10 \mathrm{~d}$ of challenge. On examining the efficacy of IVP required to elicit a response, it was

Table 1. Efficacy of inactivated virus preparation (IVP) in protecting Fenneropenaeus indicus from white spot disease. Survival (\%) on challenge with WSSV MCCV 101 after IVP administration ( $\mathrm{n}=24$ each)

\begin{tabular}{|lcccc|}
\hline \multirow{2}{*}{ Feed type } & \multicolumn{4}{c|}{ Survival (\%) } \\
& 1st day & 5th day & 10th day & 15th day \\
\hline IVP coated feed & 0 & 100 & 100 & 0 \\
Placebo & 0 & 0 & 0 & 0 \\
Normal feed & 0 & 0 & 0 & 0 \\
\hline
\end{tabular}

Table 2. Minimum quantity of inactivated virus preparation (IVP) required to protect Fenneropenaeus indicus against white spot disease. Survival (\%) after challenge with WSSV MCCV 101

\begin{tabular}{|lcc|}
\hline & \multicolumn{2}{c|}{ Survival (\%) } \\
\cline { 2 - 3 }$\left(\mathrm{IVP}^{-1} \mathrm{feed}\right)$ & $\begin{array}{c}\text { 5th day } \\
\text { post IVP } \\
\text { administration } \\
(\mathrm{n}=18)\end{array}$ & $\begin{array}{c}\text { 10th day } \\
\text { post IVP } \\
\text { administration } \\
(\mathrm{n}=18)\end{array}$ \\
\hline $0.025 \mathrm{~g}$ & 100 & 100 \\
$0.05 \mathrm{~g}$ & 100 & 100 \\
$0.075 \mathrm{~g}$ & 100 & 100 \\
$0.1 \mathrm{~g}$ & 100 & 100 \\
Control (normal feed) & 0 & 0 \\
\hline
\end{tabular}

found that the lowest effective quantity was $0.025 \mathrm{~g}$ IVP dry weight $\left(\mathrm{LD}_{50} 3.69 \times 10^{12.69}\right) \mathrm{g}^{-1}$ feed (Table 2).

Shrimp that survived challenge after the IVP administration schedule also showed 100\% survival and absence of gross signs of WSD upon 4 subsequent challenges carried out consecutively at $15 \mathrm{~d}$ intervals with WSSV-infected prawn meat.

Shrimp that survived WSSV challenge on the 5th day after completion of the IVP administration schedule were tested on the 10th day post challenge for the presence of WSSV by single step and nested PCR assays. None gave positive results (Fig. 2). In contrast, the gill tissue of animals challenged on the 10th day after the completion of administration of IVP gave amplicons for the first step PCR (650 bp amplicon) and second step (nested) PCR (300 bp amplicon) (Fig. 2). Despite the positive test results, the shrimp appeared healthy and showed no gross signs of disease and no mortality.

\section{DISCUSSION}

Formalin was used to inactivate WSSV because of its ability to cross-link proteins and to stabilize antigenic

\section{M 891011121314}

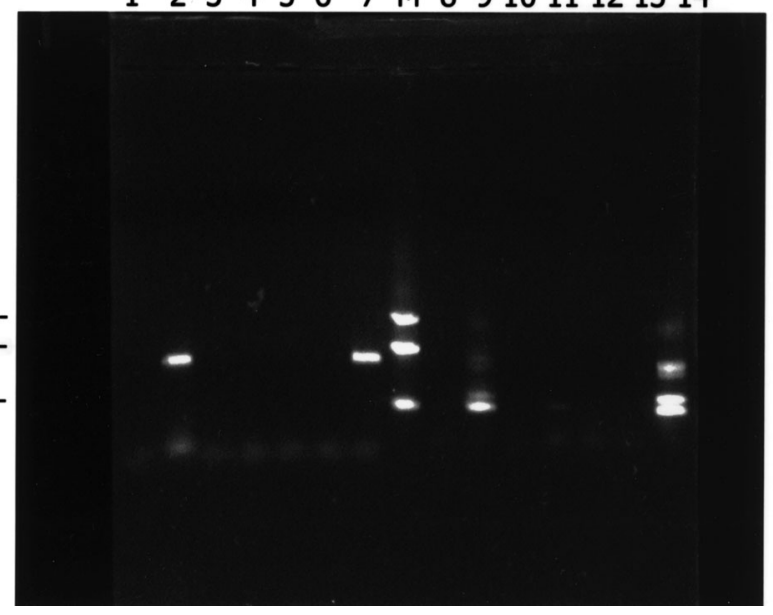

Fig. 2. Two-step PCR assay for detection of WSSV MCCV101 in Fenneropenaeus indicus fed inactivated viral preparation (IVP) for $7 \mathrm{~d}$ and then challenged with WSSV-infected meat on the 5th or 10th day after cessation of IVP feeding. Lane M: marker $(1000,700$, and $300 \mathrm{bp})$; Lanes 1 to 7: 1-step PCR product (650 bp); Lanes 8 to 14: nested PCR products (300 bp); Lanes 1 and 8: PCR negative controls; Lanes 2 and 9: PCR positive controls; Lanes 3 and 10: $F$. indicus fed on normal diet and not challenged with WSSV MCCV101; Lanes 4 and 11: $F$. indicus fed on normal diet and challenged with WSSV MCCV101; Lanes 5 and 12: F. indicus fed IVP for $7 \mathrm{~d}$ and not challenged with WSSV MCCV101; Lanes 6 and 13: F. indicus fed IVP for $7 \mathrm{~d}$ and challenged with WSSV MCCV101 on the 5th day after cessation of IVP feeding; Lanes 7 and 14: F. indicus fed IVP for $7 \mathrm{~d}$ and challenged with WSSV MCCV101 on the 10th day after cessation of feeding IVP 
epitopes (Wesslen et al. 1957, Bottiger et al. 1958, Barteleng \& Woortmeyer 1984). Formalin treatment was found to be better for enhancing WSSV resistance than heat treatment as used by Namikoshi et al. (2004). The optimum treatment for virus inactivation after successive freezing and thawing cycles was $48 \mathrm{~h}$ exposure to $0.2 \% \mathrm{v} / \mathrm{v}$ formalin. However, the preparation was maintained at $4^{\circ} \mathrm{C}$ for $9 \mathrm{~d}$ to ensure total inactivation of the virus and any bacteria and fungi that might also have been present in the shrimp tissue macerates. The shrimp fed IVP for $7 \mathrm{~d}$ were found to resist WSSV infection from $5 \mathrm{~d}$ and until $10 \mathrm{~d}$ after feeding but before and after this, they were vulnerable to infection and subsequent death. The protective effect did not arise from normal shrimp tissue (placebo) components. The $7 \mathrm{~d}$ schedule of IVP administration was adopted based on the work of Takahashi et al. (2000), who found it most effective for oral administration of immunostimulants. A similar requirement of a few days to elicit an immunological response has previously been reported (Sung et al. 1994, Teunissen et al. 1998).

Since shrimp that survived WSSV challenge on the 5th day after cessation of IVP feeding were negative for WSSV by nested PCR assays, the results suggest that they were refractory to WSSV for at least some interval following IVP administration. This refractory interval is comparable to that which occurs in vertebrates and is mediated by immunoglobulins that react with specific antigens and facilitate their elimination by subsequent phagocytosis. The results are similar to those of Adams (1991) and Teunissen et al. (1998) described in the 'Introduction' and suggest the possibility of some sort of memory for different pathogens in shrimp. Therefore, we propose to focus subsequent research on tests for the existence of specific molecules that might be produced in response to inactivated WSSV and bind with it to facilitate its elimination by subsequent phagocytosis. Should such molecules be discovered, they might be named 'viricidins'.

Surprisingly, a different result was obtained with shrimp that were challenged $10 \mathrm{~d}$ after cessation of IVP feeding. Instead of being negative for WSSV by PCR, they were positive even by a single-step assay although they showed no signs of disease. This suggested that they were able to accommodate WSSV and survive. This situation resembled viral accommodation as proposed by Flegel \& Pasharawipas (1998) and experiments on a quasi-immune response (Venegas et al. 2000, Namikoshi et al. 2004, Witteveldt et al. $2004 \mathrm{a}, \mathrm{b})$ as described in the 'Introduction'. As part of the quasi-immune response, a cell-mediated defense mechanism has been proposed by Hasson et al. (1999). Wu et al. (2002) also demonstrated WSSV neutralizing activity in plasma of infected shrimp from $20 \mathrm{~d}$ to more than 2 mo. Namikoshi et al. (2004) concluded that the quasi-immune response molecule was heat labile. These studies and our observations confirm the phenomenon of acquired resistance or a quasi-immune response in shrimp. In addition, our detection of WSSV-PCR positive survivors from a WSSV challenge $10 \mathrm{~d}$ following cessation of IVP feeding exactly matches the observations of Venegas et al. (2000).

Our study indicates the existence of 4 phases in the immune response of shrimp, subsequent to administration of IVP, even though the beginning and end of these phases could not be sharply demarcated. These phases are named the 'immune activation phase' (1st to 4th day post IVP administration), the 'refractory phase' (5th to 9th day post IVP administration), the 'viral accommodation phase' (10th to 14th day post IVP administration) and the 'immune declining phase' (15th day onwards). The lack of clear demarcation between phases may result from variation in different batches of shrimp but could not be gauged in our experimental design. Despite this, the demarcations may be useful in analyzing results from further investigations.

The concept of protecting shrimp from WSSV by oral administration of IVP gains added support from the observation that they subsequently survive repeated challenges with WSSV. The subsequent challenges could be regarded as broadly equivalent to booster 'vaccinations' in vertebrates. Thus, despite lack of knowledge on the shrimp immune system, available information suggests that periodic oral administration of IVP or envelope proteins such as VP19 and VP28 (Witteveldt et al. 2004b) at $10 \mathrm{~d}$ intervals may prolong protection against WSSV. The process of IVP administration may be economically viable since the quantity required for eliciting a response in recipient shrimp is very small $\left(0.025 \mathrm{~g}\right.$ IVP $\mathrm{g}^{-1}$ feed $\mathrm{w} / \mathrm{w}$ having an approximate virus titre $\mathrm{LD}_{50} 3.68 \times 10^{12.69}$ ).

The term 'vaccine' denotes any substance used to stimulate the production of antibodies that result in immunity to a specific disease. In shrimp, antibody-like molecules that specifically bind with a respective antigen have not been discovered. Therefore, it would be premature to call the inactivated WSSV preparation a 'vaccine' and that is why we describe it as an inactivated virus preparation (IVP). This contrasts with the nomenclature previously used with the WSSV recombinant envelope proteins VP9 and VP28 that were referred to as sub-unit vaccines (Witteveldt et al. $2004 a, b)$. Despite the fact that the mechanisms is unknown, this investigation and previous studies unequivocally reveal that shrimp have a true adaptive and specific immune response that can be elicited by repeated oral administration of IVP and result in protection against WSD. A major point of interest is that protection against WSD does not always equate to absence of WSSV infection. 
Acknowledgements. This work was carried out with the financial assistance from The Indian Council of Agricultural Research (Project Code: 0624004), New Delhi. We thank Dr. R. H. Reed, School of Applied Sciences, Northumbria University, Newcastle upon Tyne, UK, for reviewing the language of the manuscript.

\section{LITERATURE CITED}

Adams A (1991) Response of penaeid shrimp to exposure to vibrio species. Fish Shellfish Immunol 1:59-70

Arala-Chaves M, Sequeira T (2000) Is there any kind of adaptive immunity in invertebrates? Aquaculture 191: 247-258

Barteleng SJ, Woortmeyer R (1984) Formaldehyde inactivation of foot and mouth disease virus, conditions for the preparation of safe vaccine. Arch Virol 80:103-117

Bettencourt R, Lanz-Mendoza H, Faye I (1997) Cell-adhesion properties of hemolin, an insect immune protein in the Ig superfamily. Eur J Biochem 250:630-637

Bottiger M, Lycke E, Melen B, Wrange G (1958) Inactivation of poliomylitis virus by formaldehyde. Incubation time in tissue culture of formalin treated virus. Arch Ges Virusforsch 3:259-266

Faye I (1990) Acquired immunity in insects: the recognition of non-self and the subsequent onset of immune protein genes. Res Immunol 141:927-932

Flegel TW, Pasharawipas T (1998) Active viral accommodation: a new concept for crustacean response to viral pathogens. In: Flegel TW (ed) Advances in shrimp biotechnology. National Center for Genetic Engineering and Biotechnology, Bangkok, p 245-250

Hasson KW, Lightner DV, Mohney LL, Redman RM, White BM (1999) Role of lymphoid organ spheroids in chronic Taura Syndrome Virus (TSV) infections in Penaeus vannammei. Dis Aquat Org 38:93-105

Itami T, Takahashi Y, Nakamura Y (1989) Efficacy of vaccination against vibriosis in cultured kuruma prawns Penaeus japonicus. J Aquat Anim Health 1:234-242

Itami T, Yan Y, Takahashi Y (1992) Studies on vaccination against vibriosis in cultured kuruma prawn Penaeus japonicus. I. J Shimonoseki Univ Fish 40:83-87

Johansson MW (1999) Cell adhesion molecules in invertebrate immunity. Dev Comp Immunol 23:303-315

Johansson MW, Soderhall K (1988) Isolation and purification of a cell adhesion factor from crayfish blood cells. J Cell Biol 160:1795-1803

Johansson MW, Soderhall K (1989) Cellular immunity in crustaceans and the Pro PO system. Parasitol Today 5: 171-176

Johansson MW, Lind ML, Holmblad T, Thornqvist PO, Soderhall K (1995) Peroxinectin a novel cell adhesion protein

Editorial responsibility: Timothy Flegel,

Bangkok, Thailand from crayfish blood. Biochem Biophys Res Commun 216: 1079-1087

Landenhorff NE, Kanost MR (1991) Bacteria-induced protein P4 (hemolin) from Manduca sexta: a member of the immunoglobulin super-family which can inhibit hemocyte aggregation. Arch Insect Biochem Physiol 18:285-300

Mendoza HL, Faye I (1996) Immunoglobulin superfamily proteins in invertebrates. In: Soderhall K, Sadaaki I, Vasta G (eds) New directions in invertebrate immunology. SOS Publications, Fair Haven, NJ, p 285-302

Namikoshi A, Wu JL, Yamashita T, Nishizawa T, Nishioka T, Arimoto M, Muroga K (2004) Vaccination trials with Penaeus japonicus to induce resistance to white spot syndrome virus. Aquaculture 229:25-35

Reed LJ, Muench H (1938) A simple method of estimating fifty per cent end points. Am J Hyg 27:493-497

Soderhall K, Cerenius L (1992) Crustacean immunity. Annu Rev Fish Dis 2:3-23

Sun SC, Lindstrom I, Boman HG, Faye I, Schmit O (1990) Hemolin: an insect immune protein belonging to the immunoglobulin superfamily. Science 250:1729-1732

Sung HH, Kuo GH, Song YL (1994) Vibriosis resistance induced by glucan treatment in tiger shrimp (Penaeus monodon). Fish Pathol 29:11-17

Takahashi $\mathrm{Y}$, Kondo $\mathrm{M}$, Itami $\mathrm{T}$, Honda $\mathrm{T}$, Ingawa $\mathrm{H}$, Nishizawa T, Soma GI, Yokomizo Y (2000) Enhanncement of disease resistance against penaeid shrimp acute viremia and induction of virus-inactivating activity in hemolymph of kuruma shrimp, Penaeus japonicus, by oral administration of Pantoea agglomerans lipopolysaccharide (LPS). Fish Shellfish Immunol 10:555-558

Teunissen OSP, Faber R, Booms GHR, Latscha T, Boon JH (1998) Influence of vaccination on vibriosis resistance of the giant black tiger shrimp Penaeus monodon (Fabricius). Aquaculture 164:359-366

Venegas CA, Nonaka L, Mushiake K, Nishizawa T, Muroga K (2000) Quasi-immune response of Penaeus japonicus to penaeid rod- shaped DNA virus (PRDV). Dis Aquat Org 42:83-89

Wesslen T, Lycke E, Gard S, Olin G (1957) Inactivation of poliomyelitis virus by formaldehyde. Arch Ges Virusforsch 7:125-135

Witteveldt J, Vlak JM, van Hulten MCW (2004a) Protection of Penaeus monodon against white spot syndrome virus using a WSSV subunit vaccine. Fish Shellfish Immunol 16: 571-579

Witteveldt J, Cifuentes CC, Vlak JM, van Hulten MCW (2004b) Protection of Penaeus monodon against white spot syndrome virus by oral vaccination. J Virol 78:2057-2061

Wu JL, Nishioka T, Mori K, Nishizawa T, Muroga K (2002) A time-course study on the resistance of Penaeus japonicus induced by artificial infection with white spot syndrome virus. Fish Shellfish Immunol 13:391-403

Submitted: May 12, 2003; Accepted: April 27, 2005

Proofs received from author(s): September 5, 2005 